\title{
Human in Vitro Fertilization: Lessons from Unrealized Fears and Unexpected Benefits
}

\author{
Radko Rajmon ${ }^{1}$, Miroslava Krejčová ${ }^{1}$, Jaroslav Petr $^{2}$ \\ ${ }^{1}$ Czech University of Life Sciences in Prague, Faculty of Agrobiology, Food and Natural Resources, \\ Department of Veterinary Sciences, Prague, Czech Republic \\ ${ }^{2}$ Institute of Animal Science, Prague, Czech Republic
}

\section{LIDSKÁ FERTILIZACE IN VITRO: NENAPLNĚNÉ OBAVY A NEOČEKÁVANÉ VÝHODY}

ABSTRAKT Za tři desetiletí se technika in vitro oplození proměnila z oboru, v který věřil jen málokdo, na techniku, která je pevnou součástí moderní medicíny. Obavy, které s ní byly spojovány, se nenaplnily. Naopak, in vitro oplození našlo uplatnění i tam, kde to nikdo nepředpokládal. V kombinaci s předimplantační genetickou diagnostikou se využívá jako prevence dědičných onemocnění. Potřeba oplození in vitro se ukázala i v zemích třetího světa, které se potýkají s důsledky populační exploze.

V současnosti se rozvíjejí nové biotechnologie, které narážejí na odpor veřejnosti. Historie se opakuje. Jsou zdůrazňovány především jejich možná i ryze hypotetická rizika a mnohé jejich budoucí přínosy nejsou a za současného stavu poznání ani nemohou být předvídány. Rozvoj in vitro oplození nabízí lekci pro hodnocení nastupujících biotechnologií. Jejich výrazné omezení nebo dokonce zákaz by zjevně znamenaly pro budoucnost lidstva závažná omezení.

KLÍČOVÁ SLOVA biotechnologie; bioetika; IVF; rizika a př́nosy

ABSTRACT During the past three decades, human in vitro fertilization (IVF) has changed from disdained technique to one which constitutes a respected branch of modern medicine. Concerns connected with human in vitro fertilization have not materialized. On the other hand, in vitro fertilization has demonstrated benefits in unexpected areas. When combined with techniques of molecular genetics such as preimplantation genetic diagnostics, it can prevent the occurrence of hereditary diseases. In vitro fertilization is greatly needed even in developing countries, despite the fact that the Third World is heavily confronted with the impacts of population explosion.

At present, many new and promising biotechnologies are fighting strong opposition from the public. The history of human IVF recurs. Even hypothetical risks are emphasized, and many future benefits are not recognized or cannot be recognized at the present state of knowledge.

The significant progress of human IVF provides us with a lesson for the evaluation of impending biotechnologies. The setting of rigid limits or imposing bans on new biotechnologies can significantly restrict the future prosperity of mankind.

KEY WORDS biotechnology; bioethics; IVF; risks and benefits

\section{DIFFICULT EARLY DAYS OF HUMAN IN VITRO FERTILIZATION}

The awarding of the Nobel Prize for Physiology and Medicine in 2010 to Robert G. Edwards "for the development of in vitro fertilization" (Nobel Assembly at Karolinska Institutet, 2010) confirmed the magnitude of this medical technique for our present world. However, the first news about a child born after in vitro fertilization (IVF) (Steptoe - Edwards, 1978) met both with euphoria and reluctance. Even the initial research which opened the way to this breakthrough was opposed by fierce discussions (Johnson et al., 2010).

The basics of human IVF were established in 1969 (Edwards et al., 1969). However, further progress in this area met with strong resistance even within the scientific community. Fauser and Edwards (2005) stated that "at one stage, Edwards had only three or four supporters at Cambridge". According to Martin Johnson of Cambridge University, one of Edward's first graduate students, there was a "strange atmosphere" in the 1960s and 1970s with regard to human in vitro fertilization (Abbott 2010). Even Cambridge Nobel laureates Max Perutz and James Watson did not hesitate to express their opinion that it is "irresponsible to interfere with the beginning of life" (Abbott, 2010).

In 1971 the British Medical Research Council (MRC) refused to approve a grant to Edwards and Steptoe for research on human in vitro fertilization. The MRC rationalized this by stating that the treatment of human infertility has a "low 
priority compared with population control”. The MRC perceived research on human fertilization as "purely experimental rather than potential treatment" (Johnson et al., 2010). The negative decision in 1971 influenced the attitude of the MRC to human IVF for the next eight years. Only after the birth of two healthy babies from IVF did the MRC swiftly convert to enthusiastic support of human in vitro fertilization.

More than four million children were born over more than three decades using IVF. During this time it was clearly demonstrated that many fears and doubts were unfounded. Fears of low biological safety of IVF (Johnson et al., 2010) or fear of profound social changes induced by the introduction of IVF (Baslington, 1996; Hanmer, 1987; Mies, 1985) did not materialize. The attitudes of religious communities and churches differed substantially. There is still a wide spectrum of attitudes - strict rejection by the Catholic Church, tolerance in Protestant, Anglican and other Christian denominations, and the positive attitude of Judaism and Islam when IVF is used for conception of a child by husband and wife (Schenker, 2005).

\section{BIOETHICAL QUESTIONS OF IVF}

Discussion on the bioethical aspects of IVF and other techniques of so-called assisted reproduction (AR) continues despite the fact that these techniques are widely accepted as an integral part of modern medicine. Critics focus not on assisted reproduction per se but rather on some special aspects of $A R$, and especially on individual controversial cases.

Pregnancy of postmenopausal women performed by transfer of embryos conceived in vitro from donated oocytes (Borini et al., 1995) is often strongly criticized. The advanced age of the mother, even over seventy, does not guarantee that the mother will be able to care for the child for the necessary period. For this reason, IVF cannot be used for the purpose of pregnancy in postmenopausal women in some countries, and these women are denied treatment using assisted reproduction. Such a decision raises the question of the ethical acceptance of such denials and also raises the question if there is a reason to deny assisted reproduction to other people with reduced ability to fulfill parental duties, e. g., to drug addicts or alcoholics.

A very complicated situation can occur after donation of oocytes, sperm or embryos (Van Voorhis et al., 1999; Murray Golombok, 2000; Frith, 2001) because there are several people who are bound to the child by strong bonds - emotional, legal or biological. Anonymous donation of gametes or embryos prevents a conceived child from knowing about his biological parents. However, the introduction of an onymous donation of gametes or embryos has been accompanied by a sharp decline in the number of donors (Janssens et al., 2006).

A very complicated situation could arise concerning deciding about the fate of cryopreserved embryos when the opinions of the biological parents differ. One parent wants to implant embryos and conceive a baby, but this is strongly rejected by the other parent. This issue is difficult to decide because one of the fundamental principles is that the fate of cryopreser- ved embryos must be agreed upon by both biological parents (Smajdor, 2007; Sozou et al., 2010). Another significant bioethical and even legal question accompanies the use of surrogate mothers for the development of embryos of foreign parents (van Niekerk - van Zyl, 1995; Poster, 1989).

These discussions became more heated after every really controversial case connected with IVF or assisted reproduction, e.g., after intentional transfer of a high number of embryos with the intention of establishing a multiple pregnancy (Ory, 2010; Rosenthal, 2010). On January 26, 2009, Nadya Suleman gave birth to octuplets and became famous. Over the course of one month Ms. Suleman became a subject of outrage and outrageous representations over conception by in vitro fertilization and of the details of her personal life. This thirty-yearsold single woman chose to have in vitro fertilization since she already had six children from in vitro fertilization with other men.

\section{NEW BENEFITS OF ASSISTED REPRODUCTION}

Many expected negative effects of in vitro fertilization have not occurred. Just the opposite was the case. In vitro fertilization served as the starting platform for other techniques of assisted reproduction which alleviated many complicated cases of human infertility. Cryoconservation of embryos (Trounson - Moor, 1994) is one such complementary technique of assisted reproduction. It enables the storage of surplus embryos conceived by in vitro fertilization of multiple oocytes retrieved from a patient after hormonal stimulation. Cryopreserved embryos can be used by their biological parents for conceiving other children without another hormonal treatment of the mother and without the procedure of oocyte retrieval. Intracytoplasmatic sperm injection (ICSI) allows the fertilization of oocytes by sperm which are for various reasons unable to penetrate the oocyte (Palermo et al., 1993). ICSI enables even fertilization of human oocytes with earlier developmental stages of male gametes, e.g., elongated spermatids or rounded spermatids (Fishel et al., 1997). This opened the way to fatherhood to men with seriously damaged spermatogenesis. In vitro fertilization is employed even in areas which were quite unexpected in the early days of development of this technique. This is the case of preimplantation genetic diagnosis (PGD), which involves IVF even in fully fertile couples (Handyside et al., 1990). PGD is used for the prevention of heritable diseases. IVF is performed in couples which encounter the possibility that their child will be born with a heritable disease such as cystic fibrosis, Duchenne muscular dystrophy or hemophilia. One or two cells are removed from embryos cultured in vitro and the DNA of these cells is subjected to genetic analysis focusing on selected mutations. Only embryos without genetic defects are transferred to the mother, and therefore it is sure, that the newborn baby will not suffer from a heritable disease. Before PGD, the only options for the prevention of heritable diseases were prenatal genetic diagnosis and artificial abortion. 
PGD is really a breakthrough in the prevention of heritable diseases. However, even PGD brings its own controversies. The majority of the public perceives deafness as a disability which should be prevented. These people might agree with PGD which prevents the birth of a child with heritable deafness. However, a small part of the deaf community prefers the birth of a deaf child. These so called "capital-D-Deaf" do not perceive deafness as a disability but rather as a culture which they want to share with their children (Davis, 1997; Lane, 2002).

\section{IVF FOR THE THIRD WORLD}

In vitro fertilization is quite paradoxically a technique which can alleviate many problems of inhabitants of the Third World. Despite the ongoing population explosion, infertility is a very serious problem in developing countries. There are about 80 million infertile people in the world, and the majority of them live in the Third World. These people have no access to regular, basic health care. Access to therapy for infertility is even much more limited. When compared to the Western World, infertility has much stronger negative consequences in developing countries. It is often accompanied by social isolation, economic deprivation and even brutal violence against infertile women.

The main reasons for female infertility in developing countries are sexually transmitted diseases, unsafe abortions and postpartum infections. Prevention can bring significant improvement of this sorry condition. However, in many infertile women only assisted reproduction can bring help. This treatment is affordable for only a very limited number of wealthy people in the Third World and is inaccessible for most of those who need it. There is a huge effort to develop simple and cost-effective techniques of assisted reproduction which could be applied in Third World countries for the treatment of infertility and for a solution to the complex of social problems emanating from infertility (Ombelet, 2007).

\section{EMBRYONIC STEM CELLS AND OTHER NEW BIOTECHNOLOGIES}

Approximately at the time when the Nobel Assembly announced the award of the Nobel prize to Robert Edwards, the American biotechnological firm Geron Corporation began the Phase I of a clinical trial for treatment of patients paralyzed after spinal cord injury with cells derived from human embryonic stem cells (Geron Corporation, 2010).

The beginnings of this type of cell therapy were initiated by Robert Edwards and his coworkers (Steptoe et al., 1971). A solid basis for this therapy was found in 1998 after establishment of the first lines of pluripotent stem cells obtained from in vitro culture of human blastocysts (Thomson et al., 1998). These cells, called human embryonic stem cells, have unlimited ability to divide. After culture under specific in vitro con- ditions, the embryonic stem cells differentiate into every type of cell in the human body including gametes. The potential of these cells for the treatment of injuries, degenerative diseases and many other pathological states is immense. The objective of the Phase I clinical trial performed by Geron Corporation and the Shepherd Center in Atlanta was to heal the myelin sheet of damaged axons of the injured spinal cord and to recover the mobility of patients (Geron Corporation, 2010).

Treatment with cells derived from embryonic stem cells is based on the research of Robert Edwards, because embryonic stem cells are derived from cells taken from surplus human embryos produced for infertility treatment using in vitro fertilization. Treatment with human embryonic stem cells and in vitro fertilization share strong opposition from a certain part of the public.

The history of the controversial acceptance of human in vitro fertilization repeats itself with human embryonic stem cells. There are attempts to stop research on embryonic stem cells. These attempts can substantially delay or even prevent the advance of new treatments which can cure many people or even save their lives (Moreno et al., 2010).

Many other promising biotechnologies are battling similar obstacles. For example, there are attempts to create microorganisms with a minimal synthetic genome (Lartigue et al., 2009). These microorganisms could be used in the near or distant future for inexpensive and effective production of drugs, vaccines, or for cost-effective production of "green" energy. Opponents of so-called synthetic biology prefer to emphasize the potential risks and demand substantial limitation both of research and of the exploitation of the products of synthetic biology (Calvert, 2008).

Genetically modified crops also face very strong opposition (Gaskell et al., 2000; Trewavas - Leaver, 2001) although these crops could solve the problem of world famine and malnutrition in the Third World. Genetically modified organisms could be also used for the production of drugs, vaccines, elimination of toxic pollutants from soil, etc.

\section{CONCLUSIONS}

Based on experience from more than three decades of exploitation of human IVF, it is clear that humankind is able to control the development of new biotechnologies in such a manner that it can use their benefits to advantage and eliminate their potential risks. People are able to solve very complicated bioethical problems which accompany the use of assisted reproduction.

It is reasonable to assume that new emerging biotechnologies which face the opposition of the public have the same potential. Some of their benefits cannot even be anticipated. On the other hand, their potential risks are probably exaggerated.

Opposition to emerging biotechnologies is concentrated in certain parts of world. The rejection of human embryonic stem cells seems to be much stronger in the United States than in Europe. The opposition to genetically modified crops 
is much stronger in the European Union than in any other part of the world. This indicates that the roots of this opposition do not stem from a factual evaluation of biological processes, but rather from political, cultural, religious and social reasons. Objections to emerging biotechnologies are often based on emotional grounds. This does not imply that such emotion-based opposition is weak. Rather, the opposite is the case. Draconic bans and strong restrictions imposed on new emerging biotechnologies do not prevent disasters, as these disasters are easily avoidable, or they do not represent a real threat at all. Such bans and restrictions can significantly constrain possibilities of humankind to solve important future challenges.

\section{REFERENCES}

Abbott, A. (2010): Baby boom bags Nobel prize. Nature, 467, 641-642.

Baslington, H. (1996): Anxiety overflow: Implications of the IVF surrogacy case and the ethical and moral limits of reproductive technologies in Britain. Women's Studies International Forum, 19, 675-684.

Borini, A. - Bafaro, G. - Violini, F. - Bianchi, L. - Casadio, V. - Flamigni, C. (1995): Pregnancies in postmenopausal women over 50 years old in an oocyte donation program. Fertility and Sterility, 63, 258-262.

Calvert, J. (2008): The commodification of emergence: Systems biology, synthetic biology and intellectual property. Biosocieties, 3, 383-398.

Davis, D. A. (2009): The politics of reproduction: The troubling case of Nadya Suleman and assisted reproductive technology. Transforming Antropology, 17, 105-116.

Davis, D. S. (1997): Genetic dilemmas and the child's right to an open future. The Hastings Center Report, 27, 7-15.

Edwards, R. G. - Bavister, B. D. - Steptoe, P. C. (1969): Early stage of fertilization in vitro in human oocytes matured in vitro. Nature, 221, 632-635

Fishel, S. - Green, S. - Hunter, A. - Lisi, F. - Rinaldi, L. - Lisi, R. - McDermott, H. (1997): Human fertilization with round and elongated spermatids. Human Reproduction, 12, 336-340.

Frith, L. (2001): Gamete donation and anonymity. The ethical and legal debate. Human Reproduction, 16, 818-824.

Gaskell, G. - Allum, N. - Bauer, M. - Durant, J. - Allansdottir, A. - Bonfadelli, H. - Boy, B. - de Cheveigné, S. - Fjaestad, B. - Gutteling, J. M. - Hampel, J. - Jelsøe, E. - Jesuito, J. C. - Kohring, M. - Kronberger, N. Midden, C. - Nielsen, T. H. - Przestalski, A. - Rudanem, T. - Sakellaris, G. - Torgersen, H. - Twardowski, T. - Wagner, W. (2000): Biotechnology and the European public. Nature Biotechnology, 18, 935-938.

Geron Corporation (2010): Geron initiates clinical trial on human embryonic stem cell-based therapy. First patient treated at Shepherd Center in Atlanta. http://www.geron.com/investors/factsheet/pressview. aspx?id=1235

Handyside, A. H. - Kontogianni, E. H. - Hardy, K. - Winston, R. M. (1990): Pregnacies from biopsied human preimplantation embryos sexed by Y-specific DNA amplification. Nature, 344, 768-770.

Janssens, P. M. W. - Simons, A. H. M. - van Kooii, R. J. - Blokzijl, E. - Dunselman, G. A. J. (2006): A new Dutch Law regulating provision of identifying information of donors to offspring: Background, content and impact. Human Reproduction, 21, 852-856.

Johnson, M. H. - Franklin S. B. - Cottingham, M. - Hopwood, N. (2010): Why Medical Research Council refused Robert Edwards and Patrick Steptoe support for research on human conception in 1971. Human Reproduction, 25, 2157-2174.

Hanmer, J. (1987): Reproduction trends and the emergence of moral panic. Social Science and Medicine, 25, 697-704.

Lane, H. L. (2002): Do deaf people have disability. Sign Language Studies, 2, 356-379.

Lartigue, C. - Vashee, S. - Algire, M. A. - Chuang, R.-Y. - Benders, G. A. Ma, L. - Noskov, V. N. - Denisova, E. A. - Gibbon, D. G. - Assad-Garcia, N. - Alperovich, N. - Thomas, D. W. - Merryman, C. - Hutchison, C.
A. - Smith, H. O. - Venter, J. C. - Glass, J. I. (2009): Creating Bacterial Strains from Genomes That Have Been Cloned and Engineered in Yeast. Science, 325, 1693-1696.

Mies, M. (1985): 'Why do we need all this?' A call against genetic engineering and reproductive technology. Women's Studies International Forum, $8,553-560$.

Moreno, J. D. - Nolan, J. M. - Samad, E. U. - Martins, S. A. - Brozak, S. G. - Taylor, P. L. (2010): Long shadow of the stem-cell rulling. Nature, 467, 1031-1033.

Murray, C. - Golombok, S. (2000): Oocyte and semen donation: A survey of UK licensed centres. Human Reproduction, 15, 2133-2139.

Nobel Assembly at Karolinska Institutet (2010): The Nobel Prize in Physiology or Medicine 2010 Robert G. Edwards, Press Release http://nobelprize. ogr/nobel_prizes/medicine/laureates/2010/press.html

Ombelet, W. (2007): Affordable IVF for developing countries. Reproductive BioMedicine Online, 15, 257-265.

Ory, S. (2010): The American octuplet experience: A transformative event. Fertility and Sterility, 93, 337-338.

Palermo, G. - Joris, H. - Derde, M. P. - Camus, M. - Devroey, P. - Van Steirteghem, A. C. (1993): Sperm characterization and outcome of human assisted fertilization by subzonal insemination and intracytoplasmic sperm injection. Fertility and Sterility, 59, 826-835.

Poster, R. A. (1989): The ethics and economics of enforcing contracts of surrogate motherhood. Journal of Contemporary Health Law and Policy, 5, 21-31.

Rosenthal, M. S. (2010): A preventive ethics approach to IVF in the age of octuplets. Fertility and Sterility, 93, 339-340.

Schenker, J. G. (2005): Assisted reproduction practice: Religious perspectives. Reproductive BioMedicine Online, 10, 310-319.

Smajdor, A. (2007): Deciding the fate of disputed embryos: Ethical issues in the case of Natallie Evans. Journal of Experimental \& Clinical Assisted Reproduction, 4, 2.

Sozou, P. D. - Sheldon, S. - Hartshorne, G. M. (2010): Consent agreements for cryopreserved embryos: The case for choice. Journal of Medical Ethics, 36, 230-233.

Steptoe, P. C. - Edwards, R. G. (1978): Birth after the preimplantation of a human embryo. Lancet, 2, 366.

Steptoe, P. C. - Edwards, R. G. - Purdy, J. M. (1971): Human blastocyst grown in culture. Nature, 229, 132-133.

Thomson, J. A. - Itskovitz-Eldor, J. - Shapiro S. S. - Waknitz M. A. - Swiergiel, J. J. - Marshall, V. S. - Jones, J. M. (1998): Embryonic stem cell lines derived from human blastocysts. Science, 282, 1145-1147.

Trewavas, A. J. - Leaver, C. J. (2001): Is opposition to GM crops science or politics? EMBO reports, 2, 455-459.

Trounson, A. - Mohr. L. (1983): Human pregnancy following cryopreservation thawing and transfer of eight-cell embryo. Nature, 305, 707-709.

Van Niekerk, A. - van Zyl, L. (1995): The ethics of surrogacy: Women's reproductive labour. Journal of Medical Ethics, 21, 345-349.

Van Voorhis, B. J. - Grinstead, D. M. - Sparks, A. M. T. - Gerard, J. L. Weir, R. F. (1999): Establishment of a successful donor embryo program: Medical, ethical, and policy issues. Fertility and Sterility, 71, 604-608.

\section{AUTHORS}

Rajmon, Radko (born 1968 in Ústí nad Orlicí, Czech Republic) $\mathrm{He}$ graduated at Veterinary and Farmaceutical University Brno. He is interested in the topics of animal reproduction and the effects of some environmental substances on it. He works as an associated professor at the Department of Veterinary Sciences, Czech University of Life Sciences in Prague.

Krejčová, Miroslava (born 1983 in Prague, Czech Republic)

She graduated at Czech University of Life Science in Prague. Nowadays she is Ph.D student at Department of Veterinary Sciences. She is interested in the biotechnology in the reproduction of farm animals and is participant in a teaching of the anatomy of farm animal. 
Petr, Jaroslav (born 1958 in Kolín, Czech Republic)

He graduated from the Agricultural University, Prague. He works at the Institute of Animal Science, Prague, where he is engaged in the study of animal reproduction, especially in studies of mammalian oocytes. He is a Professor at the Czech University of Life Sciences in Prague.
All correspondence to: Jaroslav Petr, Institute of Animal Science, Přátelství 815, 10401 Prague 10-Uhříněves, Czech Republic. Tel.: + 420 267009646. e-mail: petr@vuzv.cz 